Primljen / Received: 23.6.2016. Ispravljen / Corrected: 12.10.2016.

Prihvaćen / Accepted: 18.11.2016. Dostupno online / Available online: 10.5.2017.

\section{Wave theory effects on behaviour of a 3D truss offshore structure}

Author:

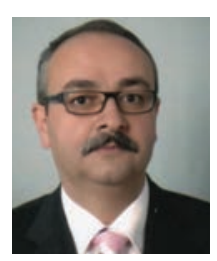

Assist.Prof. Mustafa Onüçyildiz, PhD. CE

Selçuk University

Faculty of Engineering

Department of Civil Engineering

m13yildiz@selcuk.edu.tr
Professional paper

\section{Mustafa Onüçyildiz}

\section{Wave theory effects on behaviour of a 3D truss offshore structure}

Dynamic analysis of a four legged offshore truss structure under the effect of wave forces is conducted in this study. The structure is a three-storey space frame system formed of cylindrical members whose legs are supported by lateral bracings and vertical diagonals. The structure and its environment are numerically modelled by the finite elements method with the fluid-structure interaction. Due to climatic reasons, various wave theories may be applied to the structure. Therefore, the offshore environment is modelled in numerical analysis by the Linear, Stokes 2, and Stokes 5 wave theories, separately.

Key words:

lattice trusses, offshore environment, structural behaviour, finite elements analysis

Stručni rad

\section{Mustafa Onüçyildiz}

\section{Utjecaji teorije valova na ponašanje izvanobalne prostorne rešetkaste konstrukcije}

U radu je provedena dinamička analiza izvanobalne rešetkaste konstrukcije s četiri pojasa pod utjecajem sila valova. Konstrukcija je prostorni rešetkasti sustav s tri etaže formirana od cilindričnih elemenata, a čiji su pojasi osigurani uzdužnim spregovima s vertikalnim dijagonalama. Konstrukcija i njezin okoliš su numerički modelirani metodom konačnih elemenata uz interakciju fluida i konstrukcije. Zbog klimatskih razloga, konstrukcija može biti izložena različitim teorijama valova, pa je izvanobalni okoliš modeliran pomoću zasebnih teorija valova i to linearne, Stokes 2 i Stokes 5 teorije.

Ključne riječi:

rešetkaste konstrukcije, izvanobalni okoliš, ponašanje konstrukcije, analiza konačnih elemenata

Fachbericht

\section{Mustafa Onüçyildiz}

\section{Einfluss der Wellentheorie auf das Verhalten räumlicher Offshore- Fachwerkkonstruktionen}

In dieser Arbeit werden dynamische Analysen einer Offshore-Fachwerkkonstruktion mit vier Bändern unter Welleneinwirkungen durchgeführt. Bei der Konstruktion handelt es sich um ein dreistöckiges räumliches Fachwerkssystem aus zylindrischen Elementen, deren Bänder durch Längsaussteifungen mit vertikalen Diagonalen gesichert sind. Das System und die Umgebung wurden mittels der Finite-Elemente-Methode als numerisches Modell unter Berücksichtigung der Fluid-Bauwerk-Interaktion dargestellt. Klimatisch bedingt kann die Konstruktion verschiedenen Wellentheorien ausgesetzt sein, so dass die Offshore-Umgebung basierend auf verschiedenen Wellentheorien, und zwar der linearen Theorie, sowie Stokes 2 und Stokes 5, modelliert wurde. 


\section{Introduction}

An increase in land cost and decrease in available construction land have resulted in construction of various special structures in offshore environments. Petrol platforms, wind turbines and defence industry plants are among principal examples of such special structures. In addition, large-scale offshore energy projects have been implemented in Europe and Asia with proposed farms on the rise in the United States. All existing offshore energy farms make use of the fixed bottom platform substructure. Space frame systems are the most common substructure platforms since they can be built at every depth in offshore environment. In addition, less material is used in their construction when compared to other types [1-5].

Lattice offshore truss structures can be designed as irregular, three legged and four legged structures. The most advantageous models are three and four legged ones because of materialassembly costs and production convenience. However, damage in a leg may make the structure non-utilizable in case of three legged models. Therefore, despite the higher cost, the four legged lattice type is the most widely used offshore structure, especially when considering the damage situation affecting three legged models [6-8].

IIn the design phase, offshore truss structures are designated by $X, Y, K$ and $T$ letters of the alphabet according to the shapes of the joints. Haselbacha et al. [9] named the joints of vertical diagonals in central floors as $X$, joints of the legs and vertical diagonals at the first and top floors as $Y$, and joints of vertical diagonals in the central floors as K. In the study written by Wang [10], a 3D offshore platform model with different damage cases is used to demonstrate the effectiveness of the iterative modal strain energy method. This paper is limited to theoretical and numerical investigation of the methodology. Dubois et al. [11] investigated the effects of the design of joints on the structural behaviour of offshore truss structures. The researchers have determined that the fatigue life of the truss system changes according to the design of the joints. In the study of Shi et al. [12], the mono-pile, multi-pile and jacket-type substructure design is implemented on the offshore platform. An optimum performance under dynamic load was observed in the jackettype offshore structure. The second best performance was registered for the multi-pile type model. The bidirectional fluid structure interaction is ignored in these studies [10-13]. While both the structure and the fluid are modelled in bidirectional interaction, only the structure is modelled and flow forces are transferred to the model in unidirectional interaction. Gücüyen $[14,15]$ modelled the offshore diffuser and pipeline according to the bidirectional FSI analysis. Surana et al [16] developed different mathematical models for the bidirectional FSI analysis and verified the results by numerical models. Another example of the bidirectional FSI is presented by Wang et al. [17] through the hydropower station modelling activity.

The effect of wind forces increases with an increase in the ocean sea level. However, dynamic wave forces have a greater effect on the structure compared to static ones [18]. Benitz et al. [19] described the fluid-structure interaction (FSI) analysis of an offshore structure according to the linear and non-linear wave theories. Jia [20] determined the fatigue life of lattice truss type offshore structures by considering wave forces only. Although wave forces are taken into consideration in the study, the structure is singly modelled in the numerical part of the analysis. Zhang et al. [21] considered environmental load cases in offshore structures, and conducted the dynamic pushover analysis under wave loads to see the change in the base shear force, by ignoring the fluid-structure interaction. The same analysis was applied to a four legged jacket offshore structure by Golafshani et al. [22]. While the structure is investigated under different wave models, the fluid-structure interaction is ignored.

Finite element software programs have a wide range of applications in civil engineering analyses and involve the use of various materials $[16,17]$. As many researchers avoid bidirectional FSI analyses due to several difficulties with the fluid and structure solvers, balancing time incrementation, defining contact surfaces and properties for each solver, and exploring proper mesh sizes and performing time taking calculations, this paper may fill a gap in the FSI co-simulation analyses under the effect of wave loads.

For this purpose, a truss system having bidirectional fluidstructure interaction is modelled in this study. By considering the model under the effect of various wave theories in different time spans, various wave theories are used in the fluid modelling phase to investigate the effect of theory change on structural behaviour. Numerical analysis is verified by comparison with the semi analytic-single degree of freedom model (SDOF). The accordance of structural results and fluid outputs parameters are obtained in the end.

\section{Numerical study}

The Fluid-Lagrangian technique is used in this part of the study for the bidirectional fluid-structure interaction problem. While the fluid model (Fluid) is created in the CFD solver, the structure model (Lagrangian) is formed in the Explicit solver in the Abaqus finite elements analysis software [23]. Deformations due to fluid force, and effects of these deformations on the fluid, affect each other through the fluid-structure contact surfaces.

\subsection{Structural model under consideration}

A model similar to the one given in [24] is utilized in this study, as shown in Figure 1. The structure has three storeys and each storey measures $9.00 \mathrm{~m}$ in height. Horizontal floor lengths are $10.00 \mathrm{~m}, 7.89 \mathrm{~m}, 5.77 \mathrm{~m}$, and $3.66 \mathrm{~m}$, respectively. The diameter value for 36 members in the model is $178 \mathrm{~mm}$, and wall thicknesses amount to $8.9 \mathrm{~mm}$. The lattice tower serves for $\mathrm{d}=18 \mathrm{~m}$ water depth. The non-structural mass of $1.40 \times 10^{4} \mathrm{~kg}$ is applied at four sides of the top floor. 
a)
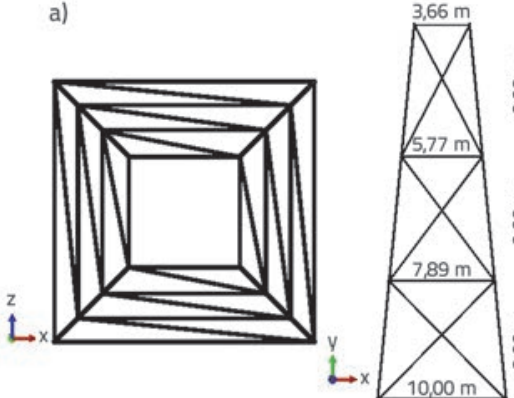

b)

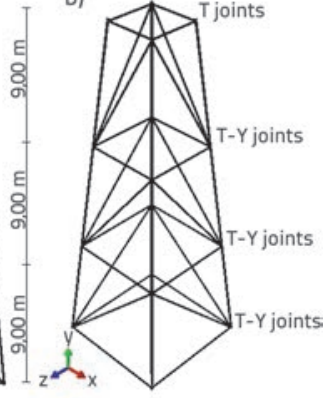

Figure 1. Structural model: a) views and storey heights; b) brace types

The model and storey heights are shown in Figure 1.a. In addition, joint details of the structure are presented in Figure 1.b. While joints of the main bearing and vertical supporting systems are named as $Y$ typed joints, the horizontal supporting system and its connection are named as T typed joints.

\subsection{Description of numerical computations and boundary conditions}

Motion of an undamped system is generally defined by Eq.(1). In this equation, $m$ represents the mass matrix, $\mathrm{k}$ is the rigidity matrix, $\mathrm{X}$ is the displacement, and $\mathrm{F}$ is the force. In addition, each point involves derivation by time.

$m \ddot{X}+k X=F$

Wave forces acting on the structure in marine environment constitute external forces presented at the right side of Eq. (1). External forces are calculated via the ABAQUS/CFD solver in the FSI analysis according to the ABAQUS co-simulation module. This solver is used for the well-known Navier-Stokes equation. The finite elements software determines wave forces by using velocity equations of wave theories instead of horizontal velocity in Navier-Stokes equations. In this paper, because analyses are performed according to the Linear, Stokes 2 , and Stokes 5 wave theories, the velocity equations of these theories shall be transferred to wave domain as inlet velocity. The formulations given by Eqs. (2-4) are for the Linear, Stokes 2, and Stokes 5 theories, respectively.

$\mathrm{u}_{\mathrm{L}}=\frac{\pi \mathrm{H}_{\mathrm{L}}}{\mathrm{T}} \frac{\cosh (\mathrm{kh})}{\sinh (\mathrm{kd})} \cos \theta$

$\mathrm{u}_{\mathrm{s}, 2}=\frac{\pi \mathrm{H}_{\mathrm{s}, 2}}{\mathrm{~T}} \frac{\cosh (\mathrm{kh})}{\sinh (\mathrm{kd})} \cos \theta+\frac{3}{4} \frac{\pi \mathrm{H}_{\mathrm{s}, 2}}{\mathrm{~T}} \frac{\pi \mathrm{H}_{\mathrm{s}, 2}}{\mathrm{~L}_{\mathrm{s}, 2}} \frac{\cosh (2 \mathrm{kh})}{\sinh ^{4}(\mathrm{kd})} \cos 2 \theta$

$u_{s, 5}=c\left(\sum_{n=1}^{5} n \phi_{n}^{\prime} \cosh (n k h) \cos (n \theta)\right)$

In the above equations, $h$ is the vertical coordinate measured upwards from seabed, $k$ is the wave number, $c$ is the wave celerity, $\phi_{n}^{\prime}$ is the wave potential coefficient, and $\theta$ is the phase angle. Mathematical formulations of these terms are presented in greater detail in [25]. In addition, $\mathrm{H}, \mathrm{T}$ and d designations denote the wave height, wave period, and water depth, respectively. Wave theory is calculated according to these three parameters, while the wave length $(L)$ is determined at the end. Wave theories and parameters used in this study are given in Table 1.

Table 1. Wave theories and parameters

\begin{tabular}{|l|c|c|c|c|}
\hline Parameter & $\begin{array}{c}\text { H } \\
{[\mathrm{m}]}\end{array}$ & $\begin{array}{c}\text { T } \\
{[\mathrm{s}]}\end{array}$ & $\begin{array}{c}\mathbf{d} \\
{[\mathrm{m}]}\end{array}$ & $\begin{array}{c}\mathbf{L}_{\mathbf{w}} \\
{[\mathrm{m}]}\end{array}$ \\
\hline Lineer & 0.50 & 6 & 18 & 56.20 \\
\hline Stokes 2 & 2.00 & 6 & 18 & 56.20 \\
\hline Stokes 5 & 8.00 & 6 & 18 & 90.60 \\
\hline
\end{tabular}

Fluid forces are calculated and transferred to the structure through contact surfaces. The ABAQUS/Explicit solver calculates displacements by means of Eq. (5), which is a variation of the equation of motion [26]:

$\left.m^{N} \ddot{X}^{N}\right|_{t}=\left.\left(F^{J}-I^{J}\right)\right|_{t}$

In Eq. (5), t represents time, FJ is the external force vector obtained from the CFD solver and IJ stands for the internal force vector occurring via stresses in the structure. Serial equations given below are used in solving equation of motion by the finite elements software. Displacements that are transferred to fluid from structure are determined in this way.

$\dot{\mathrm{X}}_{\left(\mathrm{i}+\frac{1}{2}\right)}^{\mathrm{N}}=\dot{\mathrm{X}}_{\left(\mathrm{i}-\frac{1}{2}\right)}^{\mathrm{N}}+\frac{\Delta \mathrm{t}_{(\mathrm{i}+1)}+\Delta \mathrm{t}_{(\mathrm{i})}}{2} \ddot{\mathrm{X}}_{(\mathrm{i})}^{\mathrm{N}}$

$\mathrm{X}_{(\mathrm{i}+1)}^{\mathrm{N}}=\mathrm{X}_{(\mathrm{i})}^{\mathrm{N}}+\Delta \mathrm{t}_{(\mathrm{i}+1)} \dot{\mathrm{X}}_{\left(\mathrm{i}+\frac{1}{2}\right)}^{\mathrm{N}}$

While $\mathrm{N}$ is the degree of freedom, the value i represents the time increment span for the Explicit solver in the above equations. Displacement values are calculated by $\dot{x}_{\left(i-\frac{1}{2}\right)}^{N}$ and $\ddot{X}_{i}^{N}$ which are the values that are obtained before the first increment step. Afterwards, displacements are transferred to fluid through contact surfaces, while instant changing forces are calculated according to movement of the structure. This cycle continues during the analysis. Material properties, boundary conditions, and structural members shall be defined to perform the analysis. The steps of the analysis are explained below.

Salty water is modelled using the EOS material model in wave domain. On the other hand, steel material is used to model truss domain. The wave domain with $15 \mathrm{~m} \times 15 \mathrm{~m}$ in base size, and $18 \mathrm{~m}$ in depth, is given at the left side of Figure 2. Furthermore, material properties for the wave and truss domains are given in Table 2. 
Table 2. Material properties of domains

\begin{tabular}{|c|c|c|}
\hline Truss domain & \multicolumn{2}{|c|}{ Wave domain } \\
\hline Young's modulus $(210 \mathrm{GPa})$ & Velocity of sound $(1560 \mathrm{~m} / \mathrm{s})$ & Dynamic viscosity $\left(1,50 \times 10^{-3} \mathrm{Ns} / \mathrm{m}^{2}\right)$ \\
\hline Poisson's ratio $(0,30)$ & Slope $($ Us $-U p=0)$ & Mass density $\left(1250 \mathrm{~kg} / \mathrm{m}^{3}\right)$ \\
\hline Density $\left(7850 \mathrm{~kg} / \mathrm{m}^{3}\right)$ & Grüneisen ratio $(0)$ & Temperature $\left(20^{\circ} \mathrm{C}\right)$ \\
\hline
\end{tabular}

For the flow around the stationary truss, the following boundary conditions are applied to the fluid domain in order to compute CFD. The velocity at the inlet $(u)$ is parallel to the inlet flow $x$ axis without cross stream components, as indicated in Figure 2 with red arrows. Inlet velocities for different wave theories are given via Eqs. (2-4). The other surface in $x$ direction is selected as outlet domain. Zero pressure value and no streamwise variation for velocity components are set at the outlet boundary. The bottom surface satisfies the non-slip wall boundary condition. At the remaining domain, surfaces are set for field boundary conditions, the velocity of which is assumed to be equal to inlet velocity.
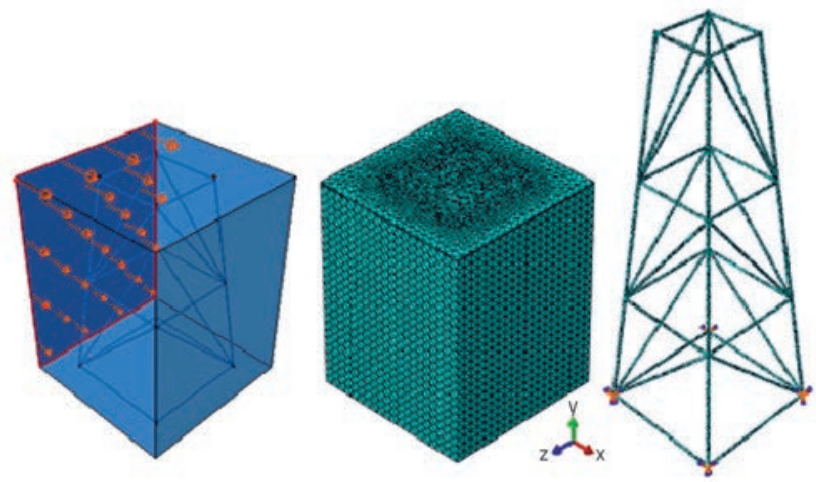

Figure 2. Boundary conditions and mesh structures of domains

In the finite elements method the models are divided into small elements to perform and analyse the complex models. While the 10-node modified tetrahedron elements (C3D10M) are used in Explicit analysis [8, 14], the 4-node modified tetrahedron elements (FC3D4) - which are suitable for FSI problems - are used in the CFD analysis. The wave model formed of FC3D4 typed members is given in the centre of Figure 2. On the other hand, the truss model formed of C3D10M members is presented at the right side of Figure 2. Joint and member numbers shall be determined after deciding on the member type. The mesh dependency study was carried out and it was demonstrated that any further increase in mesh density makes little difference on the results regarding maximum displacement of truss and maximum wave velocity. This sensitive analysis is performed for the situation in which the structure is effected by the Linear Wave Theory. While the seed size in wave domain is equal to truss domain in contact surfaces, it is $0.50 \mathrm{~m}$ at the remaining parts. Solutions for sensitivity analysis are performed for 12 $\mathrm{s}$, with the length of the step interval being $(\Delta t) 0.01 \mathrm{~s}$. The sensitivity analysis results are given in the following table.
Table 3. Outputs for varying seed sizes

\begin{tabular}{|l|c|c|c|c|}
\hline \multicolumn{1}{|r|}{$\begin{array}{r}\text { Seed size } \\
{[\mathrm{m}]}\end{array}$} & $\mathbf{0 . 0 2}$ & $\mathbf{0 . 0 1}$ & $\mathbf{0 . 0 0 7 5}$ & $\mathbf{0 . 0 0 5}$ \\
\hline Outputs & 451353 & 1998793 & 4166235 & 9312785 \\
\hline Number of nodes & 444102 & 1974882 & 4118431 & 9205928 \\
\hline Number of elements & 0.079 & 0.146 & 0.177 & 0.184 \\
\hline $\begin{array}{l}\text { Maximum displacement [m] } \\
\text { [m/s] }\end{array}$ & 0.126 & 0.238 & 0.289 & 0.302 \\
\hline
\end{tabular}

As can be seen in Table 3, when seed size decreases from 0.02 $\mathrm{m}$ to $0.01 \mathrm{~m}$, i.e. when mesh sizes are $100 \%$ densified, the node and member numbers increase by approximately 343\%. $83.64 \%$ increase in displacement value, and $89.16 \%$ in the wave velocity value, is also observed. When seed size decreases from $0.01 \mathrm{~m}$ to $0.0075 \mathrm{~m}$, the node and member numbers increase by almost $108 \%$. Besides, $20.89 \%$ increase in displacement value, and $21.15 \%$ increase in wave velocity value, is obtained. Finally, joint and member numbers increase by $123.75 \%$, displacement value increases by $4.53 \%$, and wave velocity value increases by 4.61 $\%$ for the last seed size value. While joint and member numbers increase considerably, a smaller increase is observed for the displacement and wave velocity values for the last two trials. As it is known that it is more difficult to conduct the analysis in case of an increase in joint and member numbers, the decision was made to set the seed size value to $0.0075 \mathrm{~m}$. The same value is used for the contact surfaces of the wave domain. Mesh free results are thus obtained. An optimum mesh structure is presented in Figure 2.

In addition to Explicit analysis, the modal analysis is also performed to determine natural frequency of the structure. The finite element of the model is given by the matrices shown in Eq. (8).

$[\mathrm{k}]\{\mathrm{X}\}-\lambda[\mathrm{m}]\{\mathrm{X}\}=0$

The Lanczos Method is used via the finite elements analysis software to solve Eq. (8) [23]. In Eq.(8) $\lambda$ is the square of natural frequency [27].

\section{Verification of FSI analysis and results}

In this study, the finite elements model is verified by the single degree of freedom system (SDOF) model. While the numerical 
FSI analysis is utilized for three different wave theories, the semi-analytic verification is performed for the Linear wave theory only. In the SDOF analysis, the structure is modelled as the supported and open ended single branch structure. All masses accumulate on the peak point of the structure, and the external force is applied to this mass. The equation of motion of the SDOF model is given in Eq. (9). The moment of inertia is calculated as I = $337545.41 \mathrm{~m}^{4}$ and the mass is calculated as $\mathrm{m}$ $=30184.06 \mathrm{~kg}$.

$\left(m \int_{0}^{18}(1-\cos (\pi y / 2 L))^{2} d y\right) \ddot{X}_{(t)}+\left(E I \int_{0}^{18}\left(1-\cos (\pi y / 2 L)^{\prime \prime}\right)^{2} d y\right) X_{(t)}=F_{(t)}$

Drag force and inertia force affecting 24 members of the structure are calculated according to Morison Equation defined in Eq. (10), and the total external force is obtained in the end.

$F_{(t)}=\sum_{n=1}^{24}\left(\int_{s}^{f} \frac{1}{2} \rho C_{D} D u_{n}(y, t)\left|u_{n}(y, t)\right| d y+\int_{s}^{f} \rho C_{M} \frac{\pi D^{2}}{4} \dot{u}_{n(y, t)} d y\right)$

While $s$ is the start point of unit member, $f$ is the end point Change in total force over time is presented in Figure 3.
The equation of motion is solved by the Runge-Kutta method. The dynamic start condition is stated when the displacement and velocity equal zero at $\mathrm{t}=0$ moment. The displacement function obtained by solving Eq. (9) is presented in Eq. (11).

$x_{(t)}=2,12 \sin (1,12 t+1,03)+1,49 \sin (2,32 t-0,43)+0,25 \sin (2,01 t+0,75)$

In semi-analytic solution, natural frequency of the structure $\omega_{0}$ is determined by Eq. (12).

$\omega_{0}=\sqrt{\frac{k}{m}}$

The natural frequency and displacement values from semianalytic solution and numerical analysis are compared in Table 4.

Table 4. First natural frequency and maximum displacement values in the storeys

\begin{tabular}{|c|c|c|c|c|}
\hline Analysis type & $\omega_{0}\left(\mathrm{~s}^{-1}\right)$ & $\mathbf{X}_{1}[\mathrm{~mm}]$ & $\mathbf{X}_{2}[\mathrm{~mm}]$ & $\mathbf{X}_{\mathbf{3}}[\mathrm{mm}]$ \\
\hline FEM & 7.63 & 44 & 123 & 177 \\
\hline SDOF & 7.38 & 43 & 118 & 169 \\
\hline
\end{tabular}

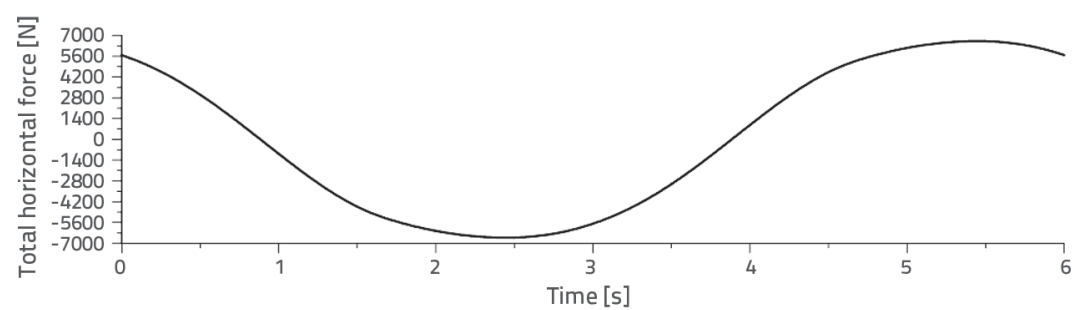

Figure 3. Time varying total external force

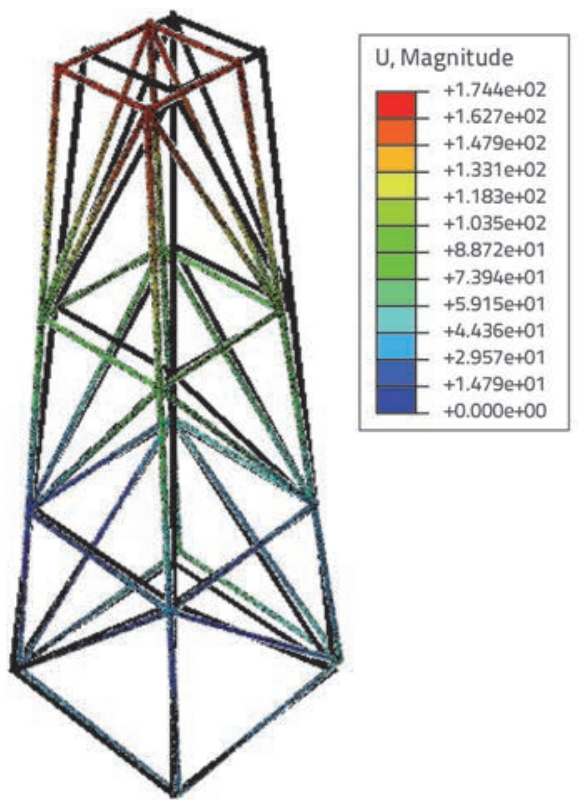

The numeric model is verified by the semi-analytic model according to the above presented results. After this verification, the model is analysed according to the Stokes 2 and Stokes 5 wave theories to detect the effect of the theories on the behaviour of the structure. Visual results for the linear wave theory are presented in Figure
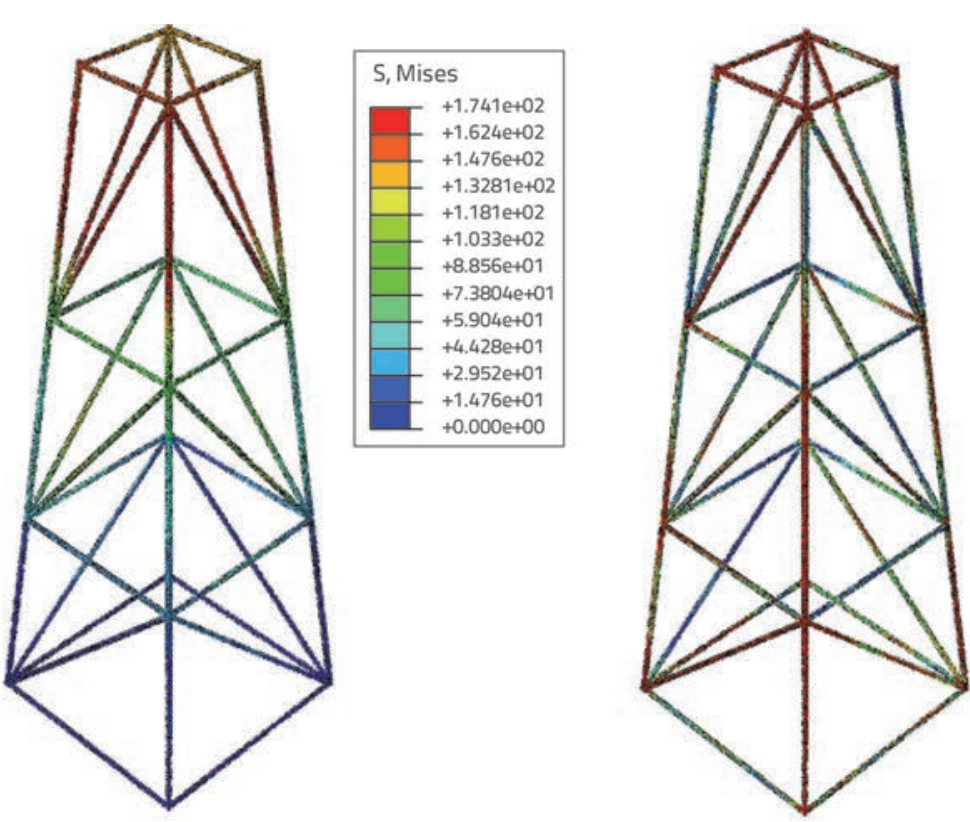

Figure 4. First mode shape, displacement and stress distributions 

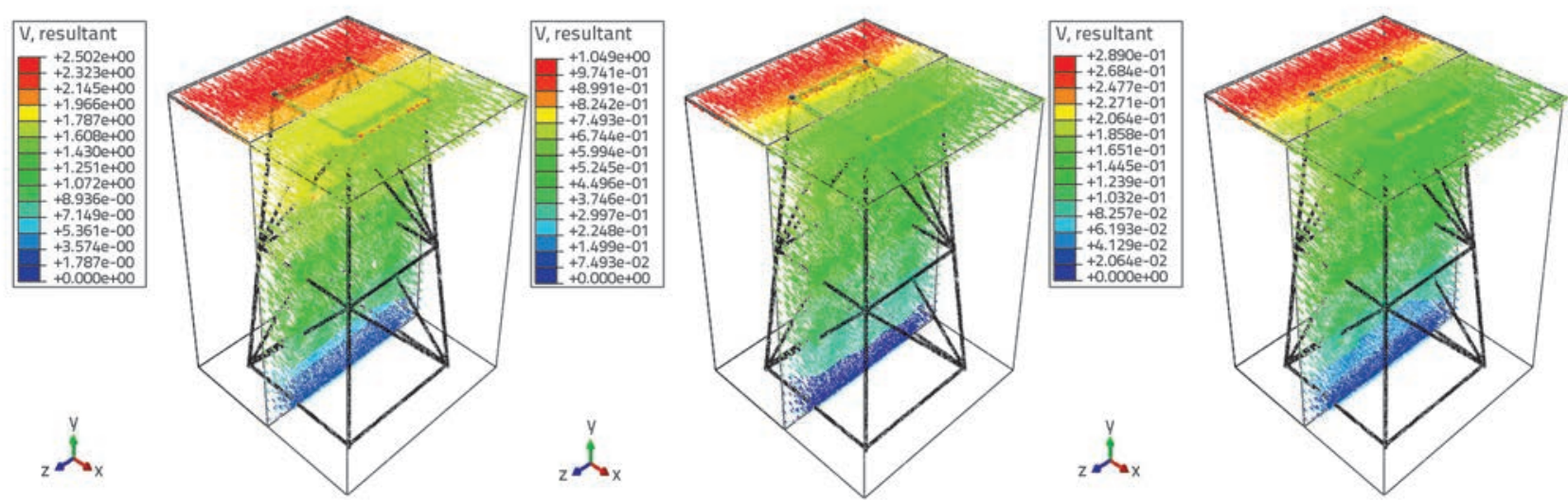

Figure 5. Plot contours and velocity vectors around the model for wave theories

4. in addition, the first mode shape, displacement, and stress distributions obtained from numeric analysis, are presented in the following figure.

Wave velocity is $2.502 \mathrm{~m} / \mathrm{s}$ in Stokes 5, $1.049 \mathrm{~m} / \mathrm{s}$ in Stokes 2, and $0.289 \mathrm{~m} / \mathrm{s}$ in linear theory according to the finite elements software. Velocity vectors belonging to these values are shown in Figure 5.

Maximum stress and displacement values on the structure due to velocity vectors in Figure 5 are given in Figure 6 as bar unit.

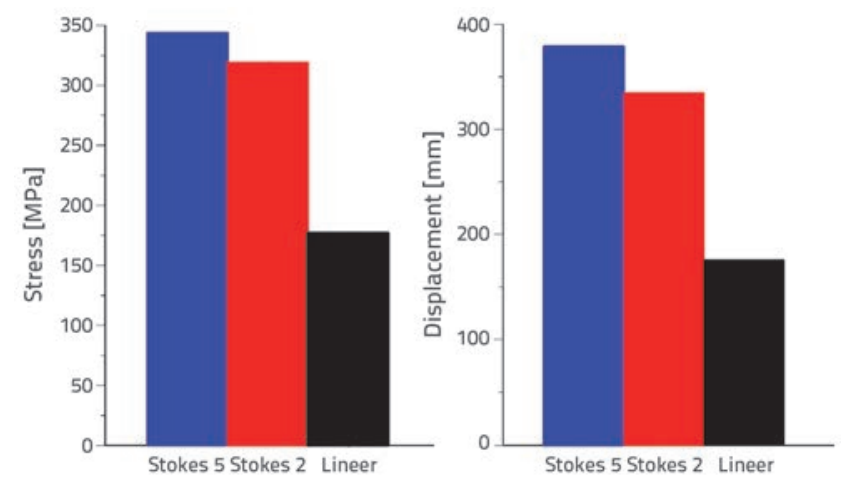

Figure 6. Maximum stress and displacement values of structure under different waves

The investigation starts with the analysis of natural frequency values. Frequency values for the first mode are given in Table 4. It is stated that the difference between the two types of analysis is $3.38 \%$. Translation is observed in the first mode shape as expected and given in Figure 4.

Displacement values according to the Linear Wave Theory are presented in Table 4 for each storey. The differences in displacement values from the first to the top storey are calculated as $2.32 \%, 4.23 \%, 4.73 \%$. The finite elements model is investigated by comparing the displacement and natural frequency values in two analyses. Figure 4 shows the mode shape, displacement distribution, and Von-Mises stress distribution on the structure. As expected, maximum displacement values are obtained at the top storey. The calculated Von-Mises stress value amounts to $177 \mathrm{MPa}$ at supports. Although stress value is higher at the top storey, the increase is smaller in comparison with the values obtained at supports.

Velocity vectors around the structure are given in Figure 5. Values regarding fluid behaviour are also determined according to the CFD analysis conducted in addition to the FEM analysis using the analysis software. The maximum wave velocity on water surface is $0.289 \mathrm{~m} / \mathrm{s}, 1.049 \mathrm{~m} / \mathrm{s}$, and $2.502 \mathrm{~m} / \mathrm{s}$, for the Linear Theory, Stokes 2, and Stokes 5, respectively. The effect of non-linear terms determining characteristic properties of the theories is observed in this way.

The displacement and stress distributions according to the Linear Theory, as shown in Figure 4, are presented for three wave theories as bar charts in Figure 6. Calculated displacement values for the Linear Theory, Stokes 2, and Stokes 5, amount to $177 \mathrm{~mm}, 335 \mathrm{~mm}$, and $379 \mathrm{~mm}$, respectively. In addition, stress values for the three theories amount to $177 \mathrm{MPa}, 3.19 \mathrm{MPa}$, and 3.44 MPa.

\section{Conclusions}

Truss type offshore structures are more sensitive and costly compared to applications on land, namely in terms of project, assembly, and sustainability. For this reason, negative cases are taken into consideration at the design phase. One of negative cases with regard to environmental forces is the effect of wave forces on the structure. The structure may be analysed according to various wave theories at different times in the ocean. So, the truss type offshore structure is influenced by different wave theories, and the natural frequencies, mode shapes, displacements, and stress values are investigated in the scope of this study. While the structure is modelled by Explicit solver, the wave model around the structure is modelled by CFD solver contained in the finite elements analysis software. Model verification is performed using the single degree of freedom system under linear wave theory. Since regular waves are repeated for one wave period or wave length, the analysis is continued for one wave period. The sizes of the fluid finite elements model increase when the analysis is performed for wave length, and it may be too difficult to 
complete the analysis. Increasing the analysis time until the wave period, instead of extending the model among wave lengths, enables simpler completion of analysis considering mesh and node numbers.

Environmental loads calculated via the CFD module of the finite elements analysis software are transferred to the structure by the FSI, and structural analysis is completed. When the model is investigated in terms of wave theories, the most critical values are obtained using the Stokes 5 theory. Although different results are obtained for Stokes 2 and Linear Theory, whose effect limits are close to each other, it is stated that these values present no risks for the structural system. It is known that the Linear Wave Theory can be used in shallow, intermediate, and deep water depths. So it actually comprises all wave theories. However, other theories shall be considered in the calculations. As a conclusion, the compatibility of the SDOF and finite elements analyses is determined. Complex solutions are needed to obtain structural parameters, except for displacement and frequency values from the SDOF analysis. In addition, it is not possible to obtain flow parameters due to semi analytic analysis. However, the FEM analysis becomes increasingly difficult with an increase in joint and member numbers reflecting the size of the structure. For this reason, the SDOF analysis may be an option when fluid parameters such as velocity profiles and accelerations, or structural parameters such as reaction forces and stress values, are not needed.

\section{REFERENCES}

[1] Thomsen, K.E.: A Comprehensive Guide to Successful Offshore Wind Farm Installation, Offshore Wind 2 ${ }^{\text {nd }}$ Edition, Elsevier, 2014.

[2] Erdem, R.T.: Analysis of The Guyed Steel Lattice Tower Due To Environmental Loads, GRADEVINAR, 67 (2015) 7, pp. 681-689, https://doi.org/10.14256/JCE.1181.2014

[3] Zwick, D., Muskulus, M., Moe, G.: Iterative Optimization Approach For The Design Of Full-Height Lattice Towers For Oshore Wind Turbines, Energy Procedia, 24 (2012), pp. 297-304, https://doi. org/10.1016/j.egypro.2012.06.112

[4] Muskulus, M.: The Full-Height Lattice Tower Concept, Energy Procedia, 24 (2012), pp. 371-377, https://doi.org/10.1016/j. egypro.2012.06.120

[5] Gücüyen, E., Erdem, R.T., Gökkuș, Ü.: Effect of Changes on Joint Connections of Steel Lattice Towers due to Environmental Loads, International Journal of Engineering and Industries, 2 (2011) 1, pp. 30-36, https://doi.org/10.4156/ijei.vol2.issue1.4

[6] Travanca, J., Hao H.: Energy Dissipation In High-Energy ShipOffshore Jacket Platform Collisions, Marine Structures, 40 (2015), pp. 1-37, https://doi.org/10.1016/j.marstruc.2014.10.008

[7] Li, H., Wang, J., James Hu, S.L.: Using Incomplete Modal Data For Damage Detection In Offshore Jacket Structures, Ocean Engineering, 35 (2008), pp. 1793-1799, https://doi.org/10.1016/j. oceaneng.2008.08.020

[8] Gücüyen, E., Erdem, R.T.: Corrosion Effects On Structural Behavior Of Jacket Type Offshore Structures, GRADEVINAR, 66 (2014) 11, pp. 981-986, https://doi.org/10.14256/JCE.1126.2014

[9] Haselbacha, P., Natarajana, A., Jiwinanguna, R.G., Branner, K.: Comparison of Coupled and Uncoupled Load Simulations on a Jacket Support Structure, Energy Procedia, 35 (2013), pp. 244-252, https://doi.org/10.1016/j.egypro.2013.07.177

[10] Wang, S.: Damage Detection in Offshore Platform Structures from Limited Modal Data, Applied Ocean Research, 41 (2013), pp. 4856, https://doi.org/10.1016/j.apor.2013.02.004

[11] Dubois, J., Muskulus, M., Schaumann, P.: Advanced Representation of Tubular Joints in Jacket Models for Offshore Wind Turbine Simulation, Energy Procedia, 35 (2013), pp. 234-243, https://doi. org/10.1016/j.egypro.2013.07.176
[12] Shi, W., Han, J., Kim, C., Lee, D., Shin, H., Park, H.: Feasibility Study of Offshore Wind Turbine Substructures for Southwest Offshore Wind Farm Project in Korea, Renewable Energy, 74 (2015), pp. 406413. https://doi.org/10.1016/j.renene.2014.08.039

[13] Gücüyen, E., Erdem, R.T., Gökkuș, Ü.: Irregular Wave Effects on Dynamic Behavior of Piles, Arabian Journal for Science and Engineering, 38 (2013), pp. 1047-1057, https://doi.org/10.1007/ s13369-012-0428-6

[14] Gücüyen, E.: Analysis of Submarine Outfalls Subjected to Wave Load, GRADEVINAR, 67 (2015) 8, pp. 799-808, https://doi.org/ 10.14256/JCE.1204.2014

[15] Gücüyen, E.: Numerical Analysis of Deteriorated Sub-sea Pipelines under Environmental Loads, Chinese Journal of Mechanical Engineering, 28 (2015) 6, pp. 1163-1170, https://doi.org/10.3901/ CJME.2015.0909.111

[16] Surana, K.S., Blackwell, B., Powell, M., Reddy, J.N.: Mathematical Models for Fluid-Solid Interaction and Their Numerical Solutions, Journal of Fluids and Structures, 50 (2014), pp. 184-216, https://doi. org/10.1016/j.jfluidstructs.2014.06.023

[17] Wang, X., Sun, R., Ao, X., Zhou, Z., Lang, J.: Eulerian-Eulerian Solid-Liquid Two-Phase Flow of Sandstone Wastewater in a Hydropower Station Rectangular Sedimentation Tank, European Journal of Environmental and Civil Engineering, 17 (2013) 8, pp.700719, https://doi.org/10.1080/19648189.2013.814551

[18] Li, M., Zhang, H., Guan, H.: Study Of Offshore Monopile Behaviour Due To Ocean Waves, Ocean Engineering, 38 (2011) 17-18, pp. 1946-1956, https://doi.org/10.1016/j.oceaneng.2011.09.022

[19] Benitz, M.A., Lackner, M.A., Schmidt, D.P.: Hydrodynamics of Offshore Structures with Specific Focus on Wind Energy Applications, Renewable and Sustainable Energy Reviews, 44 (2015), pp. 692-716, https://doi.org/10.1016/j.rser.2015.01.021

[20] Jia, J.: An Efficient Nonlinear Dynamic Approach for Calculating Wave Induced Fatigue Damage of Offshore Structures and Its Industrial Applications for Lifetime Extension, Applied Ocean Research, 30 (2008), pp. 189-198, https://doi.org/10.1016/j. apor.2008.09.003 
[21] Zhang, Y., Beer, M., Quek, S.T.: Long-Term Performance Assessment and Design of Offshore Structures, Computers and Structures, 154 (2015), 101-115, https://doi.org/10.1016/j. compstruc.2015.02.029

[22] Golafshani, A.A., Bagheri, V.H, Holmas, E.T.: Incremental Wave Analysis and Its Application to Performance-Based Assessment of Jacket Platforms, Journal of Constructional Steel Research, 67 (2011), pp. 1649-1657, https://doi.org/10.1016/j.jcsr.2011.04.008

[23] ABAQUS/CAE 6.10, 2010.
[24] Wang, S.: Damage Detection in Offshore Platform Structures from Limited Modal Data, Applied Ocean Research, 41 (2013), pp. 4856.

[25] Sarpkaya, T., Isaacson, M.: Mechanics of Wave Forces on Offshore Structures, Van Nostrand Reinhold Company, Newyork, USA, 1981.

[26] Introduction to Abaqus/Explicit, Dassault Systèmes, 2010.

[27] Reddy, J.N.: An introduction to the finite element analysis, Oxford University Press, USA, 2004. 